\title{
OLAM MODELING APPLICATIONS FOR SOUTH BRAZIL CHUVA EXPERIMENT PROJECT
}

\author{
Renato Ramos da Silva, Reinaldo Haas \\ Universidade Federal de Santa Catarina (UFSC)
}

\section{RESUMO}

Neste trabalho apresentamos os resultados obtidos com o modelo OLAM aplicado para alguns eventos ocorridos durante o experimento CHUVA que ocorreu no sul do Brasil nos arredores da cidade de Santa Maria. Os resultados mostraram que o modelo conseguiu simular com bom desempenho a distribuição e acumulação da precipitação ocorrida durante os eventos meteorológicos observados no decorrer do experimento.

\begin{abstract}
In this study we present the results obtained with the OLAM model applied to a few meteorological events that occurred during the CHUVA Experiment that was carried at the south Brazil near the city of Santa Maria. The results show that OLAM was able to simulate with great performance the distribution and accumulation of precipitation that was recorded during the meteorological events that occurred during the CHUVA field campaign.
\end{abstract}

\section{INTRODUCTION}

During the CHUVA-SUL project a series of meteorological data was recorded to improve our understanding of the systems that produces rainfall in the South Brazil. In addition, a modeling effort was taking place to evaluate the models capability to represent and to forecast those recorded events. One of the models used was the Ocean Land Atmosphere Model (OLAM). This model innovates as it permits a simultaneous global and regional simulation using a grid refining for local applications (Fig. 01). At this study, we present the OLAM results for a few case studies that were recorded during the project for the south Brazil.

\section{METHODOLOGY}

The OLAM model was set with a global grid and a high resolution for the region near the city of Santa Maria where most of meteorological instruments were deployed. A total of 04 case studies were performed with a 24-hr of model integration. Initial atmospheric conditions were obtained from NCEP/NCAR reanalysis data. Since OLAM is a global model no nudging was necessary.

Ciência e Natura Edição Especial

VIII Workshop Brasileiro de Micrometeorologia 


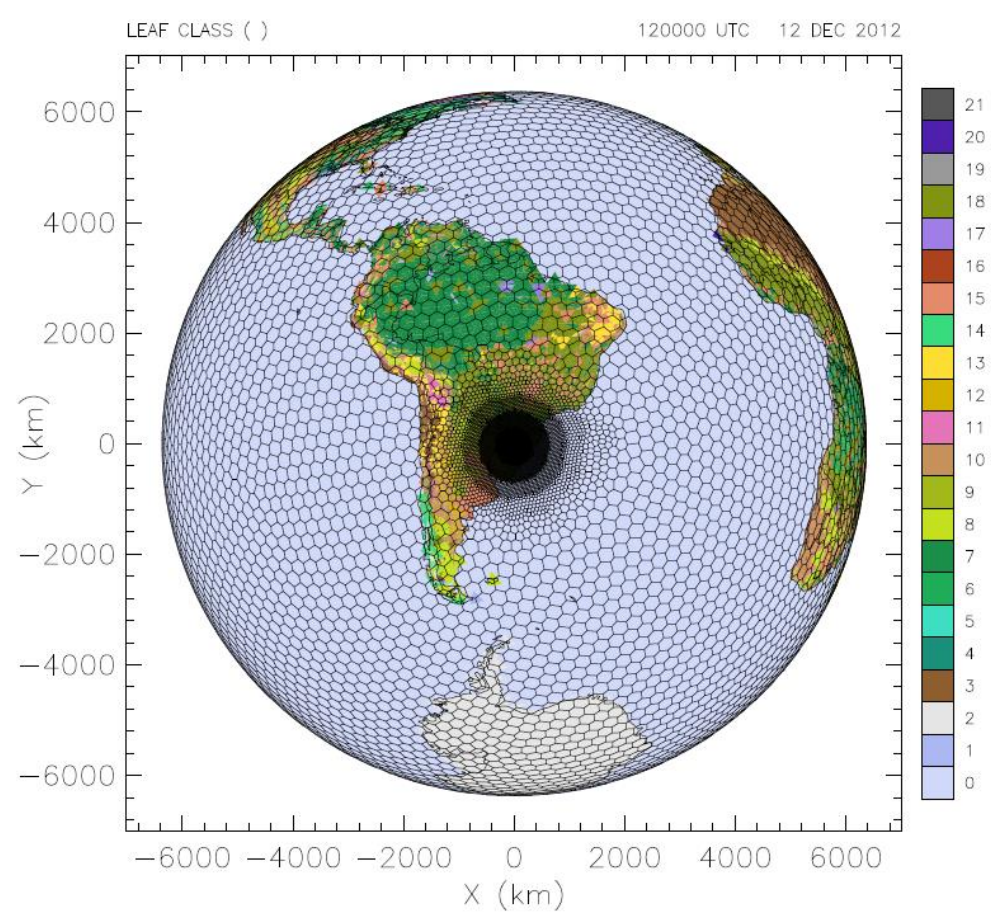

Figure 1 - OLAM grid design and vegetation types.

\subsection{Results}

Analyses of the accumulated precipitation demonstrated that OLAM was able do simulated well the distribution and the accumulation. For the case 01-02 the results showed good agreement with the observed precipitation for a few nearby locations (i.e. Cruz Alta=58 mm; Soledad= 74; Santa Maria $=12 \mathrm{~mm}$; Chui $=58 \mathrm{~mm}$ ) was in good accordance with the model results (Fig. 2). For the case 04-05 the precipitation also compared well with the radar estimates (Fig. 3) and with data from local stations (i.e. Santiago $18 \mathrm{~mm}$; Alegrete $=37 \mathrm{~mm}$; Uruguaiana $=30 \mathrm{~mm}$; Sta Maria $=20 \mathrm{~mm}$ ). For the case $06-07$ the results showed that the precipitation occurred mainly over the Uruguay in good agreement with observations (Fig. 4).

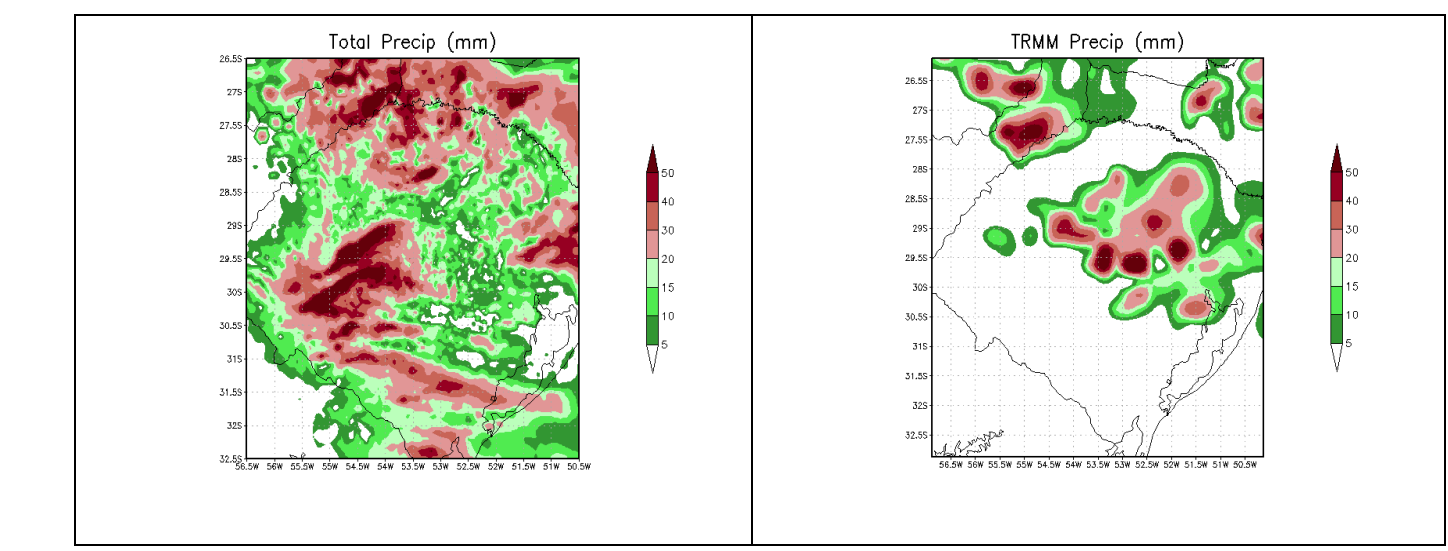

Figure 2- Accumulated precipitation $(\mathrm{mm}$ ) between 12Z-01-Dec-2012 and 12Z-02-Dec-2012 from OLAM (left) and TRMM satellite (right). 


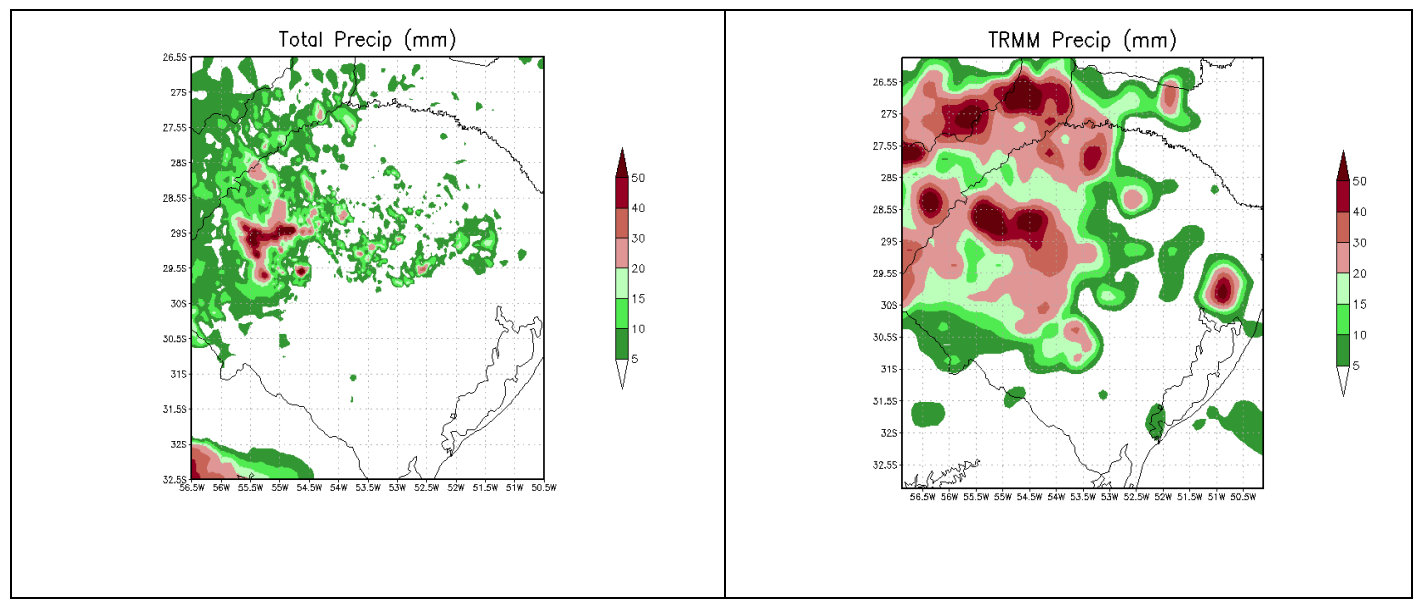

Figure 3 - Accumulated precipitation (mm) between 12Z-04-Dec-2012 and 12Z-05-Dec-2012 from OLAM (left), and TRMM satellite (right).

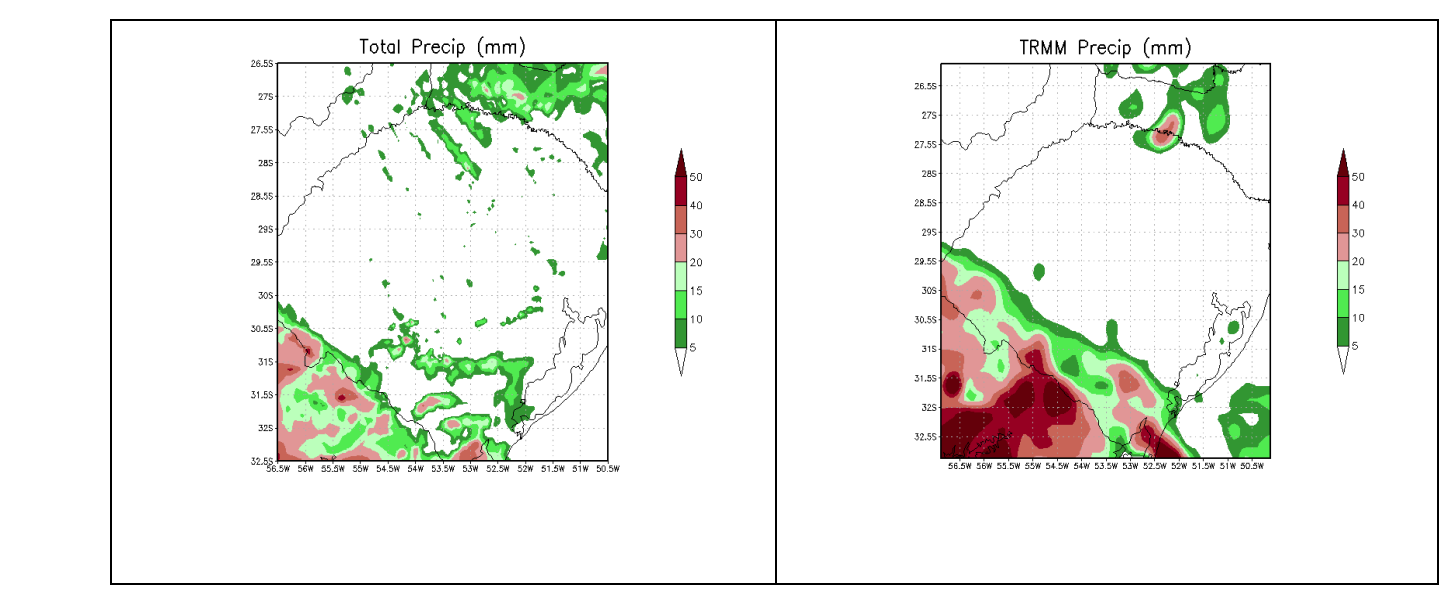

Figure 4 - Accumulated precipitation $(\mathrm{mm})$ between 12Z-Dec-06-2012 and 12Z-Dec-07-2012 from OLAM (left), and TRMM satellite (right).

The same good performance was obtained for the case 12-13. The results for this case showed very large amounts of precipitation over the state of Rio Grande do Sul and its boundaries with Argentina (Fig. 5).

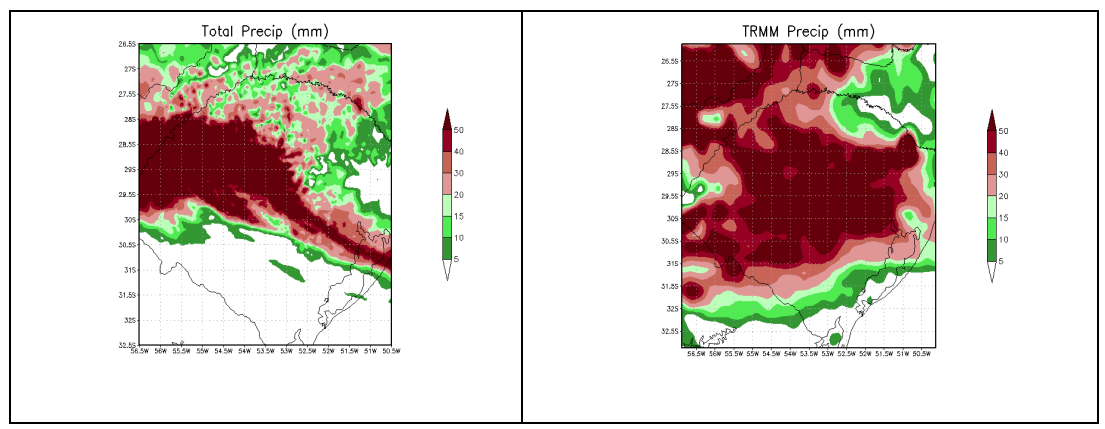

Figure 5 - Accumulated precipitation $(\mathrm{mm}$ ) between 12Z-12-Dec-2012 and 12Z-13-Dec-2012 from OLAM (left), and TRMM satellite (right).

Ciência e Natura Edição Especial

VIII Workshop Brasileiro de Micrometeorologia 


\section{CONCLUSIONS}

A series of numerical simulations were conducted to evaluate the OLAM capability to simulate the observed meteorological systems during the CHUVA-SUL Experiment that was carried on near the city of Santa Maria-RS. Comparisons between the model results and observations showed that OLAM was able to represent reasonable well the spatial distribution and the amount of precipitation. Here, preliminary results were presented, but further analysis is an ongoing research project. Since OLAM allows a two-way interaction between the global and local meteorological features, it is likely to be an important forecast tool for this region.

\section{BIBLIOGRAPHY}

RAMOS-DA-SILVA, R. and co-authors, Modelo OLAM (Ocean Land-Atmosphere Model): Descrição, aplicações e perspectivas, Revista Brasileira de Meteorologia, V. 24, 144-157, 2009. 